\title{
Changes in the energy content of common species from Hornsund, Southwest Spitsbergen
}

\author{
ANNA SZANIAWSKA AND MACIEJ WOŁOWICZ
}

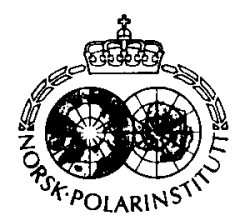

\begin{abstract}
Szaniawska, A. \& Wolowicz, M. 1986: Changes in the energy content of common species from Hornsund Southwest Spitsbergen. Polar Research 4 n.s., 85-90.

During the period August 1981 to July 1982, samples of six species of Amphipoda common to Hornsund were collected, and a study of their energy value changes was carried out. Only slight fluctuations of energy values were observed throughout the year, and no distinct seasonal changes as in the case of boreal organisms. Individuals of greater body size exhibit higher energy values. The lowest energy values $10.93 \mathrm{~kJ}$ $\mathrm{g}^{-1}$ d.w. ( $\left.\mathrm{SD}=3.01\right)$ and highest ash contents $29.8 \%(\mathrm{SD}=7.6)$ were found in small Amphipoda (e.g. Ischyrocerus anguipes), while species attaining greater body size were characterized by higher energy values and lower ash contents, for example Gammarellus homari $16.96 \mathrm{~kJ} \mathrm{~g}^{-1} \mathrm{~d} . \mathrm{w} .(\mathrm{SD}=0.50)$, and $22.9 \%(\mathrm{SD}=$ $3.3 \%$ ) ash.
\end{abstract}

Anna Szaniawska and Maciej Wotowicz, Institute of Oceanography, Gdańsk University, Czolgistów' 46, 81378 Gdynia, Poland; June 1985 (revised December 1985).

There are few data on the energy values of organisms from polar regions in the literature concerning the energy values of plants and animals (Atkinson \& Wacasey 1976; Hopkins 1979). In particular, there is a lack of information on the seasonal changes of these values (Cummins \& Wuycheck 1971; von Bast \& von Oertzen 1976; Norrbin \& Båmstedt 1984). Tabular data concerning energy values and lipid contents in 21 species of plants and animals common to Hornsund have been presented in a previous paper (Wołowicz \& Szaniawska 1986).

Amphipoda are among the most numerous species (about 500 per $\mathrm{m}^{2}$ ) of marine organisms in the Arctic (Węsławski 1983) and are also especially abundant in shallow waters (Gurjanova 1951). They constitute a basic food component for a range of animals living in polar regions, especially birds, seals and fish (Hartley \& Fisher 1936; Feder \& Jewett 1981). Knowledge of the energy values of these organisms, as well as the changes they undergo during the year, is of fundamental importance in the study of the flow of energy through the ecosystems. This paper provides data of energy values of common species from Hornsund in an annual cycle, taking into account the size of individuals.

\section{Material and methods}

The material for this paper was collected from
1981 to 1982 in Hornsund. During this period the samples of Onisimus edwardsi and Anonyx nugax were collected using bait trap at depths of 20 $30 \mathrm{~m}$. Onisimus littoralis (at 0-2 m), Gammarellus homari and Ischyroceus anguipes (at 5-15 m) were taken with a dredge. Gammarus setosus specimens (Table 1) were picked up in the tidal area. When possible, specimens of different size and sex were treated separately. Changes in the energy values of six species of Amphipoda common to this water region were determined. Measurements of the energy content were made with the help of a KMB-2 Type microbomb calorimeter. Comparison of the groups was made by the Snedecor-Fischer value ( $F$ - value) with the confidence interval at the 0.05 level. Calculations of energy values were carried out according to the methods described by Wolowicz \& Szaniawska (1986).

\section{Results}

\section{Onisimus edwardsi Kröyer}

This species is characterized by a low energy value. The mean energy value was $12.06 \mathrm{~kJ}$ $\mathrm{g}^{-1}$ d.w. (dry weight) $(\mathrm{SD}=1.97)$ and $17.16 \mathrm{~kJ}$ $\mathrm{g}^{-1}$ ash-free d.w. (SD = 2.80) (Fig. 1).

Over a one-year period, energy values for $O$. edwardsi fluctuated between 9.63 and $14.86 \mathrm{~kJ}$ $\mathrm{g}^{-1} \mathrm{~d}$.w. The highest values were observed at the 
A. Szaniawska \& M. Wolowicz

Table 1. Specification of material used in the study.

\begin{tabular}{|c|c|c|c|c|c|c|c|c|c|c|c|c|}
\hline \multirow[b]{2}{*}{ Species } & \multicolumn{5}{|c|}{1981} & \multicolumn{7}{|c|}{1982} \\
\hline & Aug. & Sept. & Oct. & Nov. & Dec. & Jan. & Feb. & Mar. & Apr. & May & Jun. & Jul. \\
\hline Onisimus edwardsi & & + & + & & & + & & & + & & + & \\
\hline$\triangle$ Onisimus littoralis & + & & + & + & + & + & & + & + & + & & \\
\hline Anonyx nugax & & + & + & & + & + & & + & + & & + & + \\
\hline$\triangle$ Gammarellus homari & & + & + & + & & & & & & + & + & \\
\hline$\triangle$ Ischyroceus anguipes $s .1$. & & + & + & + & & & & + & + & + & + & + \\
\hline$\square$ Gammarus setosus & & & & + & & + & + & + & + & & & \\
\hline
\end{tabular}

Collection by:

$\mathrm{O}$ - bait trap

$\triangle$ - dredge

$\square-$ animals were picked up.

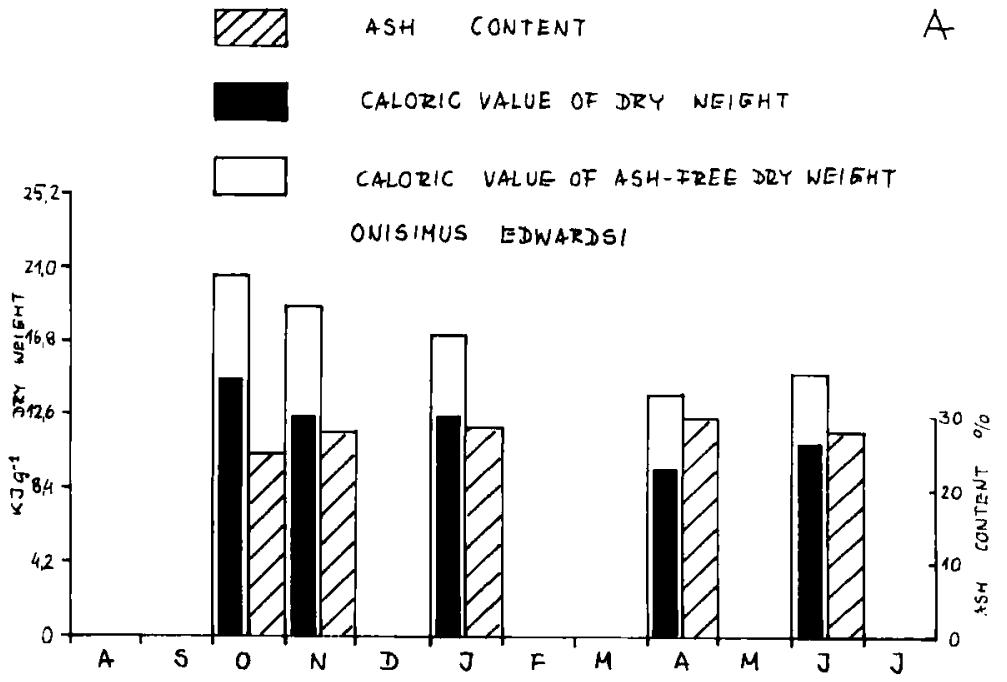

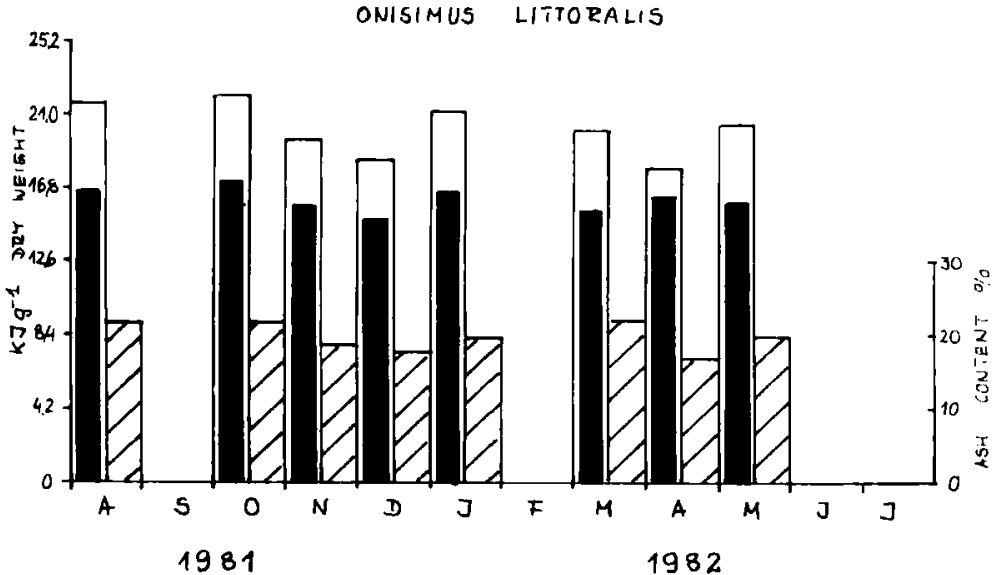

Fig. 1 . Seasonal changes in the caloric values and ash content of some common species from Hornsund. 

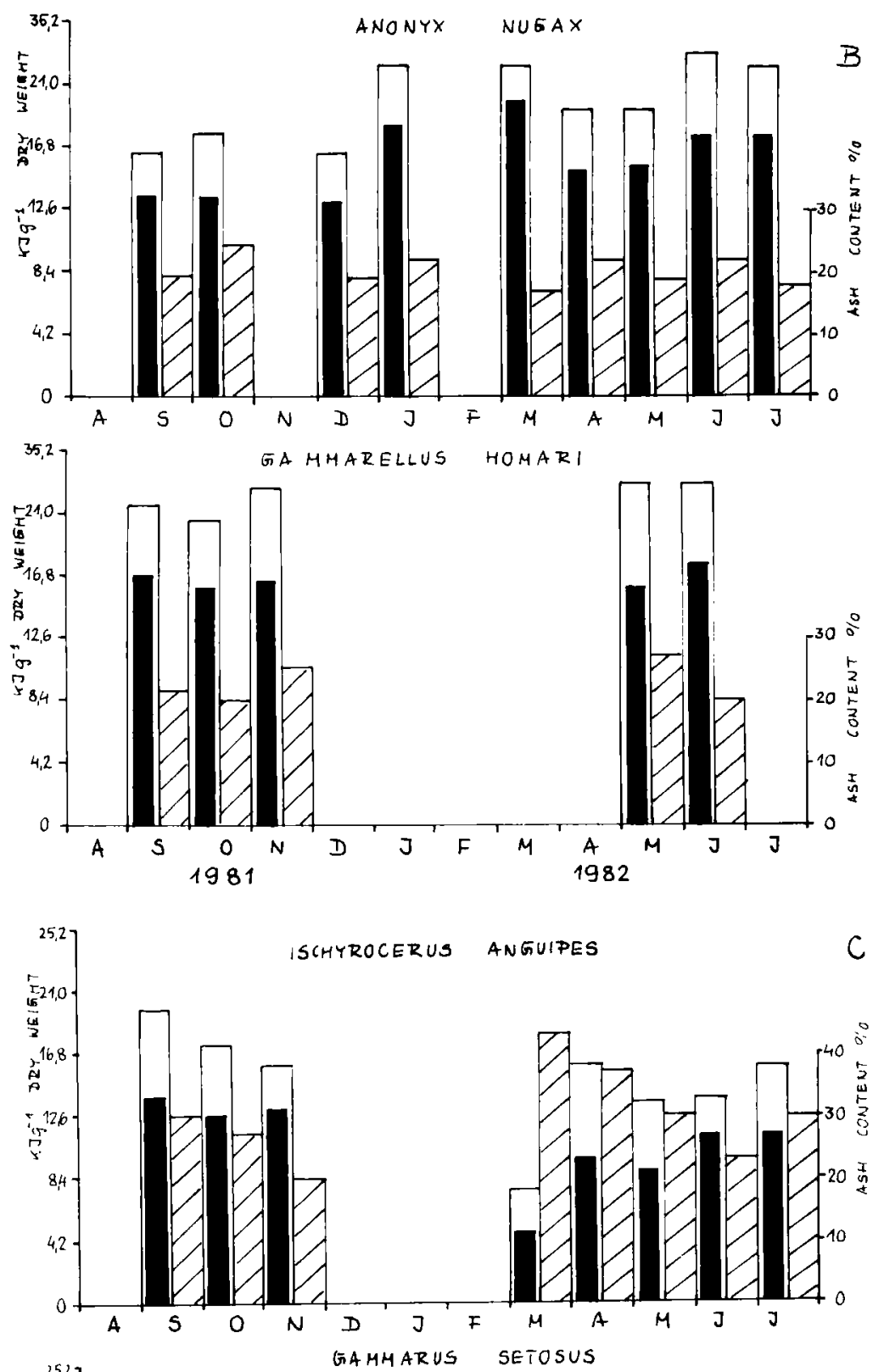

Fig. 1. Continued.

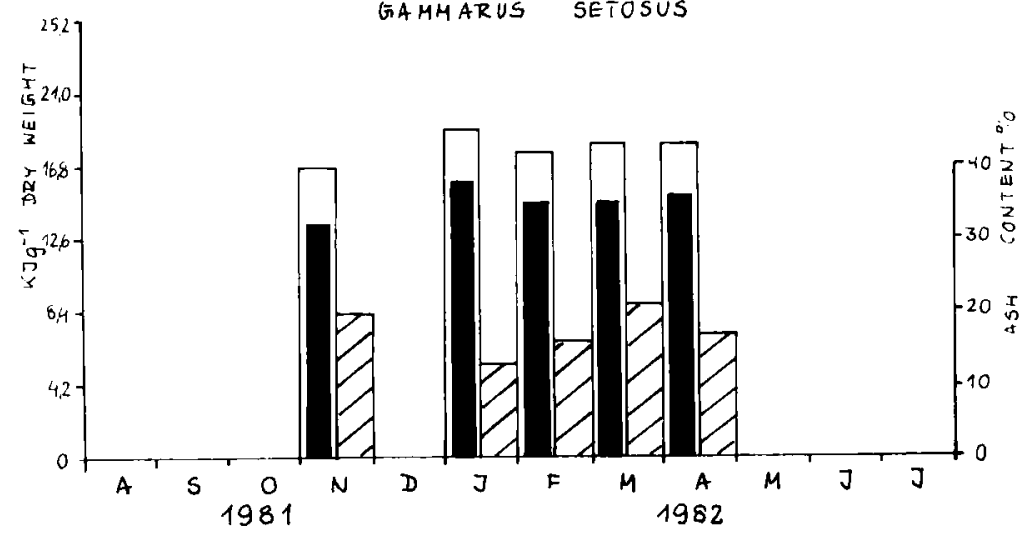


end of the summer (September), when the first females with eggs appeared and this contributed to the higher energy value of the population. Only slight differences were found in energy values in relation to the size of individuals. January specimens $7-8 \mathrm{~mm}$ long had an energy value of $12.06 \mathrm{~kJ} \mathrm{~g}^{-1} \mathrm{~d} . \mathrm{w}$. while others, $15 \mathrm{~mm}$ long had $12.39 \mathrm{~kJ} \mathrm{~g}^{1}$. O. edwardsi has high ash contents, on average $28.4 \%(\mathrm{SD}=1.7)$, which do not fluctuate much during the year.

\section{Onisimus littoralis (Kröyer 1845)}

Onisimus littoralis belongs to the most abundant species in Hornsund and constitutes an important food for seals and pelagic fish (Lydersen et al. 1985). The highest population densities are noted at a depth of 3-5 m (Węslawski 1983). No substantial seasonal changes in energy values were found during the year. Only after the intensified feeding in the spring, is there an increase in the energy value of animals, $16.33-17.16 \mathrm{~kJ} \mathrm{~g}^{-1} \mathrm{~d}$.w., as compared with the remaining period. The mean energy value of $O$. littoralis is $16.49 \mathrm{~kJ} \mathrm{~g}^{-1}$ d.w. $(\mathrm{SD}=0.79)$ and $20.51 \mathrm{~kJ} \mathrm{~g}^{-1} \mathrm{~d} . \mathrm{w}$. $(\mathrm{SD}=1.46)$ (Fig. 1). Specimens with a smaller body length have lower energy values. In December, animals $10 \mathrm{~mm}$ long had energy values of $13.44 \mathrm{~kJ} \mathrm{~g}^{-1} \mathrm{~d}$. w. $(\mathrm{SD}=0.38)$, those $20 \mathrm{~mm}$ long had $14.19 \mathrm{~kJ}$ $\mathrm{g}^{-1} \mathrm{~d} . \mathrm{w}$. $(\mathrm{SD}=0.34)$, while $20 \mathrm{~mm}$ long females with eggs attained energy values up to $18.25 \mathrm{~kJ}$ $\mathrm{g}^{-1}$ d.w. ( $(\mathrm{SD}=0.54), 4 \mathrm{~kJ} \mathrm{~g}^{-1} \mathrm{~d}$.w. more than the remaining animals with the same body length. No statistical difference was noticed, however. Compared with $O$. edwardsi, this species contains slightly less ash, $20.4 \%(\mathrm{SD}=2.1)$, but it should be noted that it is also up to $2 \mathrm{~mm}$ larger in body size.

\section{Anonyx nugax Phipps.}

The energy value of $A$. nugax calculated from material collected over a period of eight months (Table 1), was $16.66 \mathrm{~kJ} \mathrm{~g}^{-1} \mathrm{~d} . \mathrm{w} . \quad(\mathrm{SD}=2.38)$, while the corresponding ash-free value was 20.77 $\mathrm{kJ} \mathrm{g}^{-1} \mathrm{~d} . \mathrm{w}$. $(\mathrm{SD}=3.01)$. Slight differences in energy values of $A$. nugax were observed during the year (Fig. 1). Smaller individuals gave lower energy value; July specimens, $20-25 \mathrm{~mm}$ in length, had for example, values of $16.37 \mathrm{~kJ}$ $\mathrm{g}^{-1}$ d.w. ( $\left.\mathrm{SD}=0.41\right), 25-30 \mathrm{~mm}$ long specimens had $17.04 \mathrm{~kJ} \mathrm{~g}^{-1} \mathrm{~d} . \mathrm{w}$. values $(\mathrm{SD}=0.06)$ while those over $30 \mathrm{~mm}$ long had values of $19.38 \mathrm{~kJ}$ $\mathrm{g}^{-1}$ d.w. ( $\left.\mathrm{SD}=0.87\right)$. But no statistical difference was found. A separate random sample gave a result of $17.16 \mathrm{~kJ} \mathrm{~g}^{-1} \mathrm{~d} . \mathrm{w}$. ( $(\mathrm{SD}=0.95)$. Eggs were taken from females in January and found to have energy values of $17.96 \mathrm{~kJ} \mathrm{~g}^{-1} \mathrm{~d}$.w. and $23.90 \mathrm{~kJ} \mathrm{~g}^{-1}$ ash-free d.w.; the energy values of the eggs were only slightly higher than those of the female parents. The ash content of $A$. nugax was $20.3 \%(S D=2.2)$. During the period of a year it fluctuates slightly.

\section{Gammarellus homari Fabricius}

No distinct (no statistical) differences in the energy values of $G$. homari were noted (Fig. 1) in material collected over a five-month period (Table 1). The energy values for that period were $16.96 \mathrm{~kJ} \mathrm{~g}^{-1}$ d.w. $(\mathrm{SD}=0.42), 22.27 \mathrm{~kJ} \mathrm{~g}^{-1}$ d.w. $(\mathrm{SD}=1.17)$. Compared with the other Amphipoda species this is rather high. The ash content was $22.9 \%(\mathrm{SD}=3.3)$.

\section{Ischroceus anguipes Kröyer}

I. anguipes belongs to a species with very low energy values. The mean energy values from all readings amount to $10.93 \mathrm{~kJ} \mathrm{~g}^{-1} \mathrm{~d}$.w. $(\mathrm{SD}=2.97$ ) and $15.03 \mathrm{~kJ} \mathrm{~g}^{-1}$ ash-free d.w. ( $\left.\mathrm{SD}=3.64\right)$. Small differences (no statistical) in energy values were observed during the year. The highest values were noted in the summer breeding period and autumn. In September the energy value was $14.44 \mathrm{~kJ}$ $\mathrm{g}^{-1}$ d.w. $(S D=1.67)$. The lowest energy values were noted in the first months of the year. The June samples were divided into sexes. No difference in energy value was found between females, $11.68 \mathrm{~kJ} \mathrm{~g}^{-1}$ d.w. $(\mathrm{SD}=1.29)$, and males, $11.47 \mathrm{~kJ} \mathrm{~g}^{-1} \mathrm{~d} . \mathrm{w}$. ( $(\mathrm{SD}=1.71)$. As is the case with a range of other Amphipoda, smaller specimens gave lower energy values.

This species was found to have a high mean ash content, $29.7 \%$, and fluctuations of $19.3-43.3 \%$ were also noted during the year (Fig. 1.). The highest ash content was found in the individuals with the lowest energy values.

\section{Gammarus setosus L.}

The samples of $G$. setosus were collected over a period of five months (Table 1.). The mean energy values amounted to $14.65 \mathrm{~kJ} \mathrm{~g}^{-1} \mathrm{~d} . \mathrm{w}$. $(\mathrm{SD}=1.13$ ) and $17.96 \mathrm{~kJ} \mathrm{~g}^{-1}$ ash-free d.w. ( $\left.\mathrm{SD}=0.96\right)$. The changes in energy values during that period were 


\section{AVERAGE $15,19 \mathrm{kJg}^{-1}$ FEBRUARY}

Fig. 2. Mean caloric values of Gammarus setosus body size in February and March 1982, Hornsund.

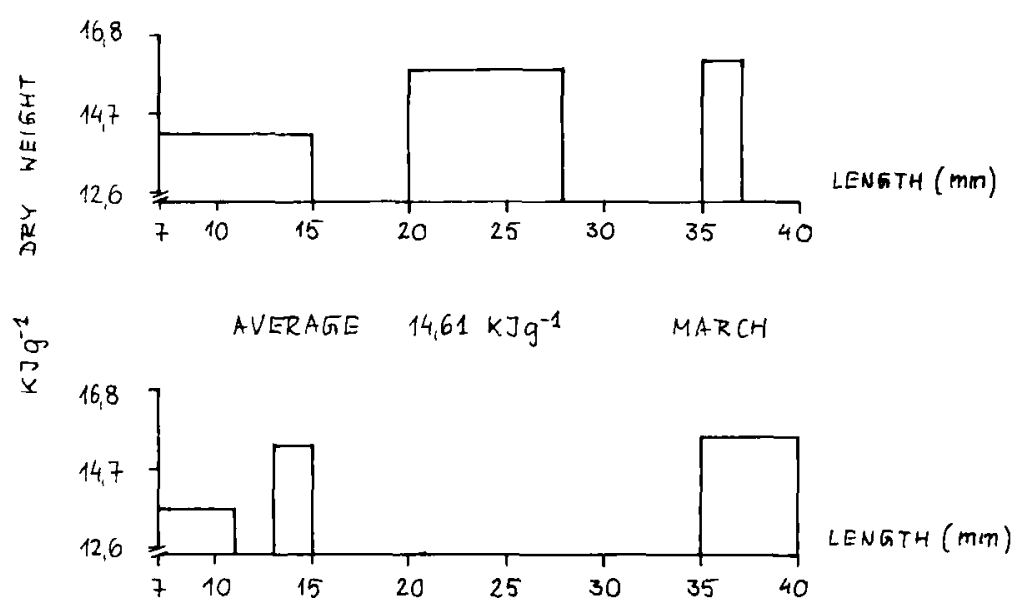

slight (Fig. 1) and dependent on the size of the specimens (but there were no statistical differences) (Fig. 2). Like the other Amphipoda specimens with small body size, $G$. setosus had low energy values. In February individuals $7-15 \mathrm{~mm}$ long had an energy value of $14.07 \mathrm{~kJ} \mathrm{~g}^{1} \mathrm{~d} . \mathrm{w}$. $(\mathrm{SD}=0.56), 20-28 \mathrm{~mm}$ long specimens had 15.49 $\mathrm{kJ} \mathrm{g}^{-1} \mathrm{~d}$.w. value $(\mathrm{SD}=0.74$ ), while $35-37 \mathrm{~mm}$ long individuals had a value of $15.99 \mathrm{~kJ} \mathrm{~g}^{-1} \mathrm{~d}$.w. $(\mathrm{SD}=0.49)$. Specimens of this species have a low ash content of $18.1 \%(\mathrm{SD}=2.9)$. Slight fluctuations in the amount of ash were noted during the study period.

\section{Discussion}

There are few data concerning the energy content of investigated Amphipoda. For $A$. nugax from the Canadian Arctic the caloric value was 24.93 $\mathrm{kJ} \mathrm{g}^{-1}$ ash-free d.w. (5955 $\mathrm{cal} \mathrm{g}^{-1}$ ash-free d.w.) (August) (Atkinson \& Wacasey 1983), and for $A$. nugax from Hornsund $24.07 \mathrm{~kJ} \mathrm{~g}^{-1}$ ash-free d.w. (July).

Small differences (no statistical) in the energy values of a range of species studied were found during the year. Some of them, e.g. O. edwardsi and $G$. homari, lead a nectobenthic way of life, where it seems that salinity and thermal conditions are almost stable throughout the year (Moskal \& Zajączkowski, in press) and would indirectly be of lesser importance for energy accumulation by animals. Seasonal changes in temperature, illumination, abundance of food base, and salinity are clearly marked only in the surface layer of the water (Węsławski 1984). Individuals are therefore not forced to take in high caloric food, except in some months, to store enough energy to enable them to survive through the harder part of the year. $O$. edwardsi and $O$. littoralis are necrophages and after the intensified feeding in the spring and summer they have the highest energy values at the end of the summer.

Distinct seasonal changes in energy values were observed, on the other hand, in Crustaceans from the boreal regions, such as Crangon crangon or Neomysis integer (Szaniawska 1983; Szaniawska et al., in press). There is a distinct seasonal character of temperature and trophicity in regions where both the above mentioned species are found. The season of the year in which the organisms are collected seems to be important for some animals. Steimle \& Terranova (1983) suggested that there are differences for many of the examined species from the northwest Atlantic continental shelf, e.g. Illex, Nephtys, Pherusa, Libinia and Ammodytes, but no such differences for Meganytiphanes norvegica and Aphrodita hostata.

Many factors influence the energy values of the individuals, the most essential ones are the phase of growth, the size of the individuals, their physiological condition, their food resources (Cummins \& Wuycheck 1971; Snow 1972). In the case of the Hornsund species studies, the changes in the energy values of Amphipoda populations probably depend on their composition, because of the higher caloric values in females with eggs and higher energy content of bigger animals. Hopkins 
(1979) states that the prawn Pandalus borealis from Balsfjord (about $70^{\circ} \mathrm{N}$, North Norway) exhibits a wide range of energy values depending on the age-groups examined. The values fluctuated between $9.53 \mathrm{~kJ} \mathrm{~g}^{-1}$ and $25.84 \mathrm{~kJ} \mathrm{~g}^{-1}$ ash-free d.w. Griffiths (1977) investigated the tendency of the calorific value to increase with the size of the organism. A linear correlation between calorific value and the length of the organism was found for some groups of zooplankton (Sushkina \& Musaeva 1980). Norrbin \& Båmstedt (1984) found a tendency towards such a correlation in material from Kosterfjorden, Sweden.

Similar energy values for males and females were noted only in Ischyroceus anguipes. On the other hand, in one range of animals it was found that females have higher energy values than males (Cummins \& Wuycheck 1971). Hermaphrodite individuals were found in the $I$. anguipes specimens, (Węsławski 1984), carrying out functions similar to those of other specimens which may influence a range of other parameters - such as energy transformation, methods of storing energy, and finally energy contents. Steimle \& Terranova (1983) suggested that for many animals, the apparent seasonal peaks appear to be positively related to gonadal maturity. The high energy value of $I$. anguipes may be connected with the fact that the reproduction of this species takes place at the end of the summer, hence during the summer females carry eggs. The low energy content in the Hornsund Amphipoda may be a result of the fact that they have only one spawning period in their life time, and there are few egg-bearing females in the population, which are therefore more difficult to find in the sampling material (Węsławski, pers. comm.).

Acknowledgements. - The authors would like to thank Dr. M. Węslawski for collection and separation of the material, and Prof. K. Wiktor for her help during the preparation of the paper.

\section{References}

Atkinson, E. G. \& Wacasey, 1976: Caloric values of zoobenthos and phytobenthos from the Canadian Arctic. Can. Fish. Mar. Serv. Tech. Rept. 632. 24 pp.
Bast, H. D. \& Oertzen, J. A. von 1976: Zusammenstellung von Energieäquivalent aquatischer Organismen unter besonderer Berücksichtigung der Ostsee. Meeresbid. Beitr. Sekt. Biol. Univ. Rostock. 25(3), 295-304.

Cummins, K. W. \& Wuycheck, L. C. 1971: Caloric equivalents for investigations in ecological energetics. Hist. Int. Ver. Limnol. 18, 1-158.

Feder, H. M. \& Jewett, S. C. 1981: Feeding interactions in the Eastern Bering Sea with emphasis on the benthos in Eastern Bering Sea Shelf. Oceanography and resources. V.II. NOA. Univ. Wash. Press, Seattle.

Griffiths, D. 1977: Caloric variation in crustacea and other animals. J. Anim. Ecol. 46, 593-605.

Gurjanova, E. F. 1951: Bokoplavy mariej SSSR i sopredelnych vod (Amphipoda-Gammaridea) Opred. po faunie SSSR. 41, 1-1029.

Hartley, C. H. \& Fischer, J. 1936: The marine foods of birds in an inland fjord region in West Spitsbergen p.2. Birds. $J$. anim. Ecol., 370-389.

Hopkins, C. C. E. 1979: Ecobiochemical studies on Pandalus borealis (Kröyer) from Balsfjord, Northern Norway. Preliminary results from a winter situation. ICES, $1979, K-31$.

Moskal, W. \& Zajączkowski, M. 1983: Outlook on the biotop of the bottom fauna in Hornsund. Zesz. Nauk. BiNoZ, UG, ser. Oceanografia.

Norrbin, F. \& Båmstedt, U. 1984: Energy contents in benthic and planktonic invertebrates of Kosterfjorden, Sweden. A comparison of energetic strategies in marine organism groups. Ophelia 23(1), 47-64.

Lydersen, C., Gjertz, I. \& Węsławski, J. M. 1985: Aspects of vertebrate feeding in the marine ecosystem in Hornsund, Svalbard. Norsk Polarinstitutt Rapportserie No. 21.

Snow, N. B. 1972: The effect of season and animal size of the caloric content of Daphnia pulicaria Forbes. Limnol. Oceanogr. 17, 902-912.

Steimle, F. W. \& Terranova, R. I. 1983: Energy equivalencies of marine organisms from the continental shelf of the Northeastern United States (unpublished manuscript).

Sushkina, E. A. \& Musaeva 1980: Energy equivalents of body mass of marine zooplanters as dependent on their sizes. Okeanologija 20, 922-930 (English summary).

Szaniawska, A. 1983: Seasonal changes in energy content of Crangon crangon L. Crustacea, Decapoda. Pol. Arch. Hydrobiol. $30(1), 45-56$.

Szaniawska, A., Wiktor, K. \& Jaruszewska-Nasińska, G. in press: Scasonal changes of energy content of Neomysis integer Leach in Gulf of Gdańsk. Oceanologia (English summary).

Wesslawski, J. M. 1983: Observations on the coastal Amphipoda of the Hornsund Fjord South West Spitsbergen. Pol. Arch. Hydrobiol. 30(3), 199-207.

Węslawski, J. M. 1984: Amphipoda Crustacea from brackish water of SW Spitsbergen (in Polish).

Wolowicz, M. \& Szaniawska, A. 1986: Calorific value, lipid content and radioactivity of common species from Hornsund, Southwest Spitsbergen. Polar Research 4, 79-84 (this volume). 